\title{
THE EFFECT OF LEADERSHIP STYLE ON MOTIVATION AND EMPLOYEE PERFORMANCE: A STUDY ON EMPLOYEES OF PT. DIPO STAR FINANCE OF MAKASSAR BRANCH, SOUTH SULAWESI
}

\author{
Rasyid Almer*, Hamid Djamhur, Nimran lqbal \\ Faculty of Administrative Science, University of Brawijaya, Indonesia \\ E-mail: almerrasyid@gmail.com
}

\begin{abstract}
This study aims to empirically examine the effect of leadership style toward work motivation and employee performance. Leadership style on this present study focuses on transformational and transactional leadership style. Samples used in this study are 57 respondents who work at PT. Dipo Star Finance in Makassar Branch. The sampling technique used is the systematic random sampling and the sampling refers to the division of work. In this study, the results show that both leadership styles significantly influence work motivation and performance of employees; there are greater influence of transactional leadership style than transformational leadership style. Indirect effect through work motivation is smaller than the direct influence of leadership style and employee performance.
\end{abstract}

\section{KEY WORDS}

Transformational leadership style, transactional leadership style, work motivation, employee performance.

In the current era of economic competition, human resources is a very important factor, as every company is very dependent on it, which ultimately determines the achievement of the goals and objectives of the company. Excellent human resources will become a driver of activities of the organization, making the company excels the lines of business. The organization's activities will run well if it has good human resources and the vice versa.

Wagimo and Ancok (2005: 112) state that there are many studies on human resources to focus on the role of leadership in organizational factors. The definition of leadership may vary depending on the perception of the individual and phenomenon in society.

A person can be said to be a transformational leader when measured from their influence toward subordinates that is based more on trust and commitment than contractual agreements. Transformational leaders help followers see the importance of achieving the vision and mission of the group or organization exceeding the benefit of the followers toward the leaders, and thus they are expected to create a strong, positive influence on the motivation and achievement of the followers (Jung \& Avolio, 1999:209). Basically, transactional and transformational leadership cannot be seen as the opposite approach in resolving all issues concerning leadership. Transformational leadership is built on transactional leadership. Bass (1990) states that all transactional leadership theory has always had a focus to attract followers or subordinates to achieve their best performance through a deal for benefits they will receive.

Changes should start from the top level or leader; this is because a leader is a role model within the organization. Transformational style proposed by Bass in Yukl (2010:305) that "Transformational leadership further improves motivation and performance of followers than transactional leadership does." In this leadership theory, according to Bass in Yukl (2010:305),"The followers feel the trust, admiration, loyalty, and respect for leaders and they are motivated to do more than what has been originally expected of them." When both of these theories are combined (transformational and transactional leadership), it is expected to give maximum impact to the followers or employees.

In addition to leadership by leaders, motivation also has an important role as motivation improves the performance of employees. The importance of motivation is disclosed by Hasibuan (2001:141) is that "motivation is a cause, distributes, and supports human behavior 
so they work hard and enthusiastically to achieve optimal results." Such motivation can stimulate employees to better mobilize energy and mind in realizing the company's goals. If the need for it is met, then there will be satisfaction and smoothness to the improvement of employee performance.

According to Sedarmayanti (2001:50), performance is also translated as achievement or outcomes. According to (Ainsworth and Smith, (2007:4), "Performance is the end point of people, resources, and certain environmental, which is gathered together with the intention to produce certain things, whether tangible products or intangible services".

Improved performance will be realized if the employees have the ability to complete the job or task that they are responsible respectively. Therefore, leaders are expected to give impetus or motivation for employees. The problem most often encountered by leaders of the organization is to find the best way to help employees have a sense of belonging for the existence and their responsibilities in the company. To address employee performance can be done by seeking the needs of employees. The needs and desires of these workers will be able to accelerate and to become the reason for employees to work as best as possible in order to achieve company's goals. Motivation then is the right way to provide energy to drive the potential of employees, to create togetherness, and to find the desire of the employees working in the organization.

Based on the descriptions above, it can be seen that in order to achieve good performance and good motivation, it takes a combination of transformational and transactional leadership style.

\section{LITERATURE REVIEW}

According to Bass (1990:230), leaders change and motivate followers by raising the level of awareness of subordinates of the interest and value of the work assigned and how to achieve it, make subordinate to think and work beyond personal interests and focus on the interest of the group of organization or community, and change level of hierarchy by expanding the needs of subordinates. Robbins (2007:472) gives the definition of transformational leadership as a leader who inspires followers to go beyond their personal interests and capable of carrying a profound and extraordinary effect on the followers.

Based on the afore-mentioned explanation, we can conclude that transformational leadership style directly and indirectly change employees by expanding their needs. This leadership styles emphasizes the positive value of the work. According to Muchiri (2002:270), a transformational leader shows charisma, inspirational motivation, intellectual stimulation, and individualized consideration. With transformational leadership, followers feel the trust, admiration, loyalty, and respect for the leaders, and they are motivated to do more than what is expected on them.

Bass (Hasibuan, 2001) states transactional leadership and transformational leadership may be found in one leader because one can display a variation of transformational and transactional leadership at the same time. Problems in an organization may vary, so are subordinates, and therefore variations of both styles of leadership are expected to provide better results in the achievement of corporate goals.

Transactional and transformational leadership cannot always been seen as a different approach to resolve any problems within the organization. Transformational leadership is built on top of transactional leadership. Transformational leadership produces higher level of effort and performance of employees, beyond what would happen with transactional leadership; and it can be conclude that "Transformational leadership is proven by the very strong relationship with a low turnover, high productivity, and higher employee satisfaction" (Pranaya, 2008).

Locke et al. (1991) discloses transactional leadership is not the opposite of transformational leadership; the opponent of this leadership style is static leadership or status quo. Locke et al. (1991) also reveals various concepts of transactions that are applied in transactional leadership style. Locke et al. (1991) state that "rewards given to followers are short-term benefits and long-term". This concept is similar to the concept proposed by 
Kunhert and Lewis (1987). They state "there are two levels of transaction between the leader and his followers, the high level of transactions and the low level of transactions" and one of which is the form of interpersonal transaction relating to transactions between the leadership with subordinates.

Table 1 - Variables and Indicators of the research

\begin{tabular}{|c|c|c|c|}
\hline \multirow{7}{*}{$\begin{array}{l}\text { Leadership Style } \\
\text { Aditya (2010) says, } \\
\text { "Transformational } \\
\text { leadership style makes } \\
\text { employees within a } \\
\text { company in a race to } \\
\text { obtain the best results } \\
\text { or targets beyond their } \\
\text { best performance.". } \\
\text { Transformational } \\
\text { leadership style } \\
\text { emphasizes } \\
\text { appreciation of goals } \\
\text { so people will have } \\
\text { confidence that their } \\
\text { actual performance will } \\
\text { exceed their expected } \\
\text { performance. }\end{array}$} & \multirow{4}{*}{$\begin{array}{l}\text { Transformational } \\
\text { Leadership Style }(X 1) \\
\text { Muchiri (2002:270) }\end{array}$} & 1. Charismatic & $\begin{array}{l}\text { Leader as an example } \\
\text { Trust toward leader } \\
\text { Leader as a regulator }\end{array}$ \\
\hline & & $\begin{array}{l}\text { 2. Inspirational } \\
\text { motivation }\end{array}$ & $\begin{array}{l}\text { Career certainty } \\
\text { Financial security } \\
\text { Leader as an example }\end{array}$ \\
\hline & & $\begin{array}{l}\text { 3. Intellectual } \\
\text { Simulation }\end{array}$ & $\begin{array}{l}\text { Chance to improve } \\
\text { Chance to share new ideas } \\
\text { Chance for creative thinking }\end{array}$ \\
\hline & & $\begin{array}{l}\text { 4. Individualized } \\
\text { consideration }\end{array}$ & $\begin{array}{l}\text { Interesting tasks } \\
\text { Leader facilitates self-development } \\
\text { Bonus }\end{array}$ \\
\hline & \multirow{3}{*}{$\begin{array}{l}\text { Transactional } \\
\text { Leadership Style (X2) } \\
\text { Gary Yukl (2004: 148) }\end{array}$} & 1. Contingent Reward & $\begin{array}{l}\text { Bonus } \\
\text { Task explanation }\end{array}$ \\
\hline & & $\begin{array}{l}\text { 1. Active Exception } \\
\text { Management }\end{array}$ & $\begin{array}{l}\text { Monitoring employee development } \\
\text { Intervention from leader }\end{array}$ \\
\hline & & $\begin{array}{l}\text { 1. Passive Exception } \\
\text { Management }\end{array}$ & $\begin{array}{l}\text { Setting standard and procedure } \\
\text { Setting reward and punishment }\end{array}$ \\
\hline \multirow[t]{3}{*}{ Motivation } & \multirow{3}{*}{$\begin{array}{l}\text { Work Motivation (Y1) } \\
\text { Winardi (2002:78) }\end{array}$} & 1. Existence Needs & $\begin{array}{l}\text { Adequate incentives } \\
\text { Feeling safe from being fired }\end{array}$ \\
\hline & & $\begin{array}{l}\text { 2. Relatedness } \\
\text { Needs }\end{array}$ & $\begin{array}{l}\text { Communication with leader } \\
\text { Communication with colleagues }\end{array}$ \\
\hline & & 3. Growth Needs & $\begin{array}{l}\text { Chance to improve career } \\
\text { Challenging tasks }\end{array}$ \\
\hline \multirow[t]{5}{*}{ Performance } & \multirow{5}{*}{$\begin{array}{l}\text { Employee } \\
\text { Performance (Y2) } \\
\text { Bernaddin and Russel } \\
\text { (1993:383) }\end{array}$} & 1. Quality of Work & $\begin{array}{l}\text { Suitability on work outcome } \\
\text { Perfect work outcome }\end{array}$ \\
\hline & & 2. Quantity of Work & $\begin{array}{l}\text { Sales exceeding target } \\
\text { Meeting the target }\end{array}$ \\
\hline & & 3. Punctuality & $\begin{array}{l}\text { Punctuality } \\
\text { Work completed after demand }\end{array}$ \\
\hline & & $\begin{array}{l}\text { 4. Ability to Work } \\
\text { Independently }\end{array}$ & $\begin{array}{l}\text { Employees follow instructions } \\
\text { Employees can work without } \\
\text { supervision }\end{array}$ \\
\hline & & $\begin{array}{l}\text { 5. Ability to Work } \\
\text { Together }\end{array}$ & $\begin{array}{l}\text { Able to develop good relationship } \\
\text { with leader } \\
\text { Able to develop good relationship } \\
\text { with colleagues }\end{array}$ \\
\hline
\end{tabular}

According to Nawawi (2005: 352) from the point of psychological theory, motivation can be divided into two categories, namely the content theory and process theory. The content theory of motivation includes the theory of Maslow's needs, the ERG theory, the two-factor theory of Hezberg, and the achievement theory. Alderfer Claytorn from Yale University develops ERG theory. ERG stands for Existence, Relatedness, and Growth. Alderfer in Winardi (2002: 78) argues that Alderfer is not satisfied with the need theory of Maslow, then he develops an alternative about human needs.

The three needs by Alderfer in Winardi (2002:79) are as follows:

a. The need for the existence (Existence Needs $=\mathrm{E}$ ) is the requirement that covers all the desires belonging to the physiological and material needs.

b. The need to belong to a group (Relatedness Needs $=R$ ) is the need to have a harmonious relationship with other parties or colleagues and satisfaction which is achieved due to a sense of belonging and a feeling of safety.

c. The needs for growth (Growth Needs $=G$ ) is the need to develop into a human being and to take advantage of the entire individual's ability to achieve their full potential. 
From the above opinion, it can be concluded that although human needs looks like a ladder as described by Maslow, however, according to Alderfe, it is not persistent, meaning that if the above requirements are already fulfilled does not mean the needs below will not be filled again.

Performance or achievements of employees are affected by many factors, which in turn is used as the basis for determining the policy of the company in order to increase and improve employee performance.

Employee assessment is a systematic evaluation of the work of employee potential that can be developed further. Assessment is the process of determination of value, quality, or the status of some objects, people or something. According to Handoko (2001:135), the performance evaluation is a process in which organizations evaluate or assess the performance of the employees.

Bernaddin and Russel (1993:383) suggest six key performance criteria that can be used to assess an employee, i.e. quality, quantity, timeliness, cost effectiveness, independence, and cooperation.

Any leader who wants to promote and enhance the company better must own good leadership style. An organization having intelligent employees and rapidly changing dynamics obviously needs transformational leadership style as capital for every leader and manager in the company.

\section{METHODS OF RESEARCH}

In accordance research objectives, this case study is explanations (explanatory research), According to Churchill (2005:29), explanatory research is a design with more emphasis on gathering ideas and inputs, and is especially useful for solving a widespread problem by making narrower and more precise sub-problems. The main emphasis of explanatory research is on the discovery of new ideas in testing new hypotheses that have been formulated to later be verifiable.

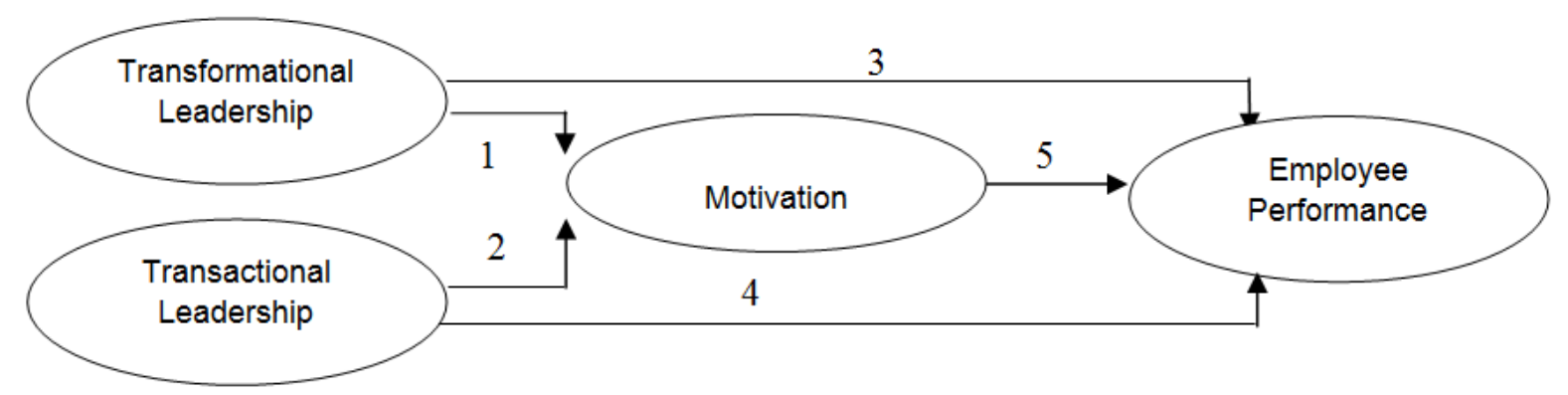

Figure 1 - Conceptual Model of the Research

The study was conducted at PT. Dipo Star Finance (DSF) Makassar Branch South Sulawesi. The company is engaged in Leasing and Finance, a subsidiary of Mitsubishi Corporation. DSF Makassar Branch is located in JL. Pengayoman 15 Makassar, South Sulawesi. The reason for choosing DSF as a research site is because DSF has advanced technology and high intelligent employees, so a transformational and transactional leadership style is needed in order to provide motivation to the improvement of employees performance.

The population in this study was the employees of DSF. DSF Makassar Branch has six divisions, i.e. Treasury, Financial, Cashiers, Administration, Marketing, and Collection, with a total population of 126 employees.

This study used systematic random sampling to determine the sample. According to Sugiyono (2010:75), systematic random sampling is sampling involves a systematic order of rules in certain populations. Probability of sampling is not the same regardless of the similarity frequency of each member of the population. To determine the sample size used in 
this study, Slovin Formula with a tolerance of $10 \%$ was used, so the number of sample used in this study was 57 respondents.

Data collection is a systematic and standard procedure to obtain the necessary data. The data was collected through questionnaires. The items on the questionnaire were closed, and respondents were provided five alternatives of answers.

Table 2 - The Relationship of Variables

\begin{tabular}{|c|c|c|c|c|}
\hline Effect & Path Coefficient & t-count & p-value & $\mathrm{R}^{2}$ \\
\hline $\mathrm{X} 1 \rightarrow \mathrm{Y} 1$ & 0.326 & 2.201 & 0.032 & $24.4 \%$ \\
\hline $\mathrm{X} 2 \rightarrow \mathrm{Y} 1$ & 0.492 & 3.322 & 0.002 & $36.8 \%$ \\
\hline Total & & & & $61.2 \%$ \\
\hline $\mathrm{X} 1 \rightarrow \mathrm{Y} 2$ & 0.276 & 2.154 & 0.036 & $21.8 \%$ \\
\hline $\mathrm{X} 2 \rightarrow \mathrm{Y} 2$ & 0.297 & 2.204 & 0.032 & $23.5 \%$ \\
\hline $\mathrm{Y} 1 \rightarrow \mathrm{Y} 2$ & 0.362 & 3.208 & 0.002 & $28.6 \%$ \\
\hline Total & & & & $73.9 \%$ \\
\hline
\end{tabular}

Source: Data processed (2015).

Note: $X 1=$ Transformational Leadership, $X 2=$ Transactional Leadership, $Y 1=$ Motivation, $Y 2=$ Performance.

\section{RESULTS AND DISCUSSION}

The coefficient of determination explains how much the model explains the path formed in explaining the data used in the study. The determination coefficient value ranges from $0.0 \%$ to $100 \%$, where the higher the coefficient of determination, the better the model in explaining the data used.

$$
\mathrm{R}_{\mathrm{m}}{ }^{2}=1-(1-0.612) \times(1-0.739)=0.899
$$

Total determination coefficient obtained based on the calculation model of the path is 0.899 that showed that the model could explain $89.9 \%$ of the data used in the study. Hypothesis one $(\mathrm{H} 1)$ tested whether there was the effect transformational leadership on employee motivation.

Table 3 - The Effect of Transformational Leadership on Employee Motivation

\begin{tabular}{|c|c|c|c|c|}
\hline Effect & Path Coefficient & Standard Error & t-count & $p$-value \\
\hline $\mathrm{X} 1 \rightarrow \mathrm{Y} 1$ & 0.326 & 0.148 & 2.201 & 0.032 \\
\hline
\end{tabular}

Note: $X 1=$ Transformational Leadership, $X 2=$ Transactional Leadership, $Y 1=$ Motivation .

The path coefficient $(\beta=0.326)$ shows that a good transformational leadership will significantly improve employee motivation, and the vice versa - unfavorable transformational leadership will significantly lower employee motivation.

Table 4 - The Effect of Transactional Leadership on Employee Motivation

\begin{tabular}{|c|c|c|c|c|}
\hline Effect & Path Coefficient & Standard Error & t-count & $p$-value \\
\hline $\mathrm{X} 2 \rightarrow \mathrm{Y} 1$ & 0.492 & 0.121 & 3.322 & 0.002 \\
\hline
\end{tabular}

Note: $X 1=$ Transformational Leadership, Y1 = Motivation. Source: Data processed (2015).

The path coefficient $(\beta=0.492)$ shows that a good transactional leadership will significantly improve employee motivation, and the vice versa-unfavorable transactional leadership will significantly lower employee motivation.

Table 5 - The Effect of Transformational Leadership on Employee Performance

\begin{tabular}{|c|c|c|c|c|}
\hline Effect & Path Coefficient & Standard Error & t-count & $\mathrm{p}$-value \\
\hline $\mathrm{X} 1 \rightarrow \mathrm{Y} 2$ & 0.276 & 0.059 & 2.154 & 0.036 \\
\hline
\end{tabular}

Note: $X 1$ = Transformational Leadership, Y2 = Performance. Source: Data processed (2015). 
The path coefficient $(\beta=0.276)$ shows that a good transformational leadership will significantly improve employee performance, and the vice versa - unfavorable transformational leadership will significantly lower employee performance.

Table 6 - The Effect of Transactional Leadership on Employee Performance

\begin{tabular}{|c|c|c|c|c|}
\hline Effect & Path Coefficient & Standard Error & t-count & p-value \\
\hline $\mathrm{X} 2 \rightarrow \mathrm{Y} 2$ & 0.297 & 0.051 & 2.204 & 0.032 \\
\hline
\end{tabular}

The path coefficient $(\beta=0.297)$ shows that a good transactional leadership will significantly improve employee performance, and the vice versa - unfavorable transactional leadership will significantly lower employee performance.

Table 7 - The Effect of Motivation on Performance

\begin{tabular}{|c|c|c|c|c|}
\hline Effect & Path Coefficient & Standard Error & t-count & $\mathrm{p}$-value \\
\hline $\mathrm{Y} 1 \rightarrow \mathrm{Y} 2$ & 0.362 & 0.052 & 3.208 & 0.002 \\
\hline
\end{tabular}

The path coefficient $(\beta=0.3 .62$ ) shows that good motivation will significantly improve employee performance, and the vice versa-bad motivation will significantly lower employee performance.

Table 8 - The Indirect Effect of Transformational Leadership on Performance through Motivation

\begin{tabular}{|c|c|c|c|c|}
\hline Effect & Path Coefficient & Standard Error & t-count & $\mathrm{p}$-value \\
\hline $\mathrm{X} 1 \rightarrow \mathrm{Y} 1 \rightarrow \mathrm{Y} 2$ & 0.118 & 0.057 & 2.081 & 0.038 \\
\hline
\end{tabular}

The path coefficient $(\beta=0.118)$ shows that a good transformational leadership will significantly improve employee performance in accordance with the increase in motivation, and the vice versa - unfavorable transformational leadership will significantly lower employee performance in accordance with the decrease in motivation.

Table 9 - The Indirect Effect of Transactional Leadership on Performance through Motivation

\begin{tabular}{|c|c|c|c|c|}
\hline Effect & Path Coefficient & Standard Error & $\mathrm{t}$-count & $\mathrm{p}$-value \\
\hline $\mathrm{X} 2 \rightarrow \mathrm{Y} 1 \rightarrow \mathrm{Y} 2$ & 0.178 & 0.051 & 3.484 & 0.001 \\
\hline
\end{tabular}

The path coefficient $(\beta=0.276)$ shows that a good transactional leadership will significantly improve employee performance in accordance with the increase in motivation, and the vice versa-unfavorable transactional leadership will significantly lower employee performance in accordance with the decrease in motivation.

The first hypothesis stating that transformational leadership has a significant effect on work motivation is accepted. The test results show there is a positive and significant effect of transformational leadership on employee motivation. It can be seen from the t-count value (2.201) which is greater than t-table (1.960) and p-value (0.032). This is consistent with the theory (Jung \& Avolio, 1999: 209) that trust, admiration, loyalty, and respect from followers to leaders is expected to create a strong, positive influence on the motivation and achievement of followers.

The second hypothesis stating that transactional leadership has a significant effect on motivation is accepted. The test results show there is a positive and significant of transactional leadership on employee motivation. It can be seen from the t-count value (3.322) greater than t-table (1960) and the p-value (0.002) which is smaller than alpha value (0.050).

The third hypothesis stating that transformational leadership has a significant effect on performance is accepted. The test results show there is a positive and significant impact of transformational leadership on performance. It can be seen from the t-count value (2.204) which is greater than t-table (1.960) and the p-value (0.032) which smaller than alpha value (0.050). The path coefficients $(\beta=0.297)$ indicates that a good transformational leadership 
will significantly improve the performance of employees, and the vice versa, unfavorable transformational leadership will significantly decrease the performance of employees.

The third hypothesis stating that transactional leadership has a significant effect on performance is accepted. The test results show there is a positive and significant impact of transactional leadership on performance. It can be seen from the t-count value (2.204) which is greater than t-table (1.960) and the p-value (0.032) which smaller than alpha value $(0.050)$. The path coefficients $(\beta=0.297)$ indicates that a good transactional leadership will significantly improve the performance of employees, and the vice versa, unfavorable transactional leadership will significantly decrease the performance of employees.

The fifth hypothesis stating that work motivation has a significant effect on the performance of employees of PT. Dipo Star Finance Makassar Branch is accepted. The test results show there is a positive and significant impact of work motivation on performance. It can be seen from the t-count value (3.208) which is greater than t-table (1.960) and the pvalue $(0.002)$ which smaller than alpha value $(0.050)$. The path coefficients $(\beta=0.362)$ shows that high motivation will significantly improve the performance of employees, and the vice versa, low motivation will significantly decrease the performance of employees.

This study contradicts the research done by Munawaroh (2011), which examines a Catholic high school in Malang, East Java. In the study, transactional leadership styles have a negative response. This occurs, as PT. Dipo Star Finance is a profit-based company in which reward and punishment will be a trigger for employees to improve performance.

\section{CONCLUSION}

The hypothesis in this study showed a significant and positive response. We can conclude that both transformational and transactional leadership style directly affects the performance of employees of PT. Dipo Star Finance. Transactional leadership style brings a good effect on performance, which is different from the study that examined an educational institution in which transactional leadership style has a negative response. For profit-based organizations, transactional leadership style is suitable to be applied by the upper-level managers.

\section{REFERENCES}

1. Ainsworth, M., Smith, N. (2002). Managing Performance Managing People: Panduan praktis untuk Memahami dan meningkatkan performa tim. Jakarta: PT. Bhuan IImu Populer.

2. Ancok, D. \& Wagimo (2005). The Impacts of Transactional and Transformational Leadership on Job Motivation in Military Personel. Jurnal Psikologi, 32, (2), 112-127.

3. Mangkunegara, A.P. (2005). Sumber Daya Manusia Perusahaan. Remaja Rosdakarya: Bandung.

4. Bass, B.M. (1990). Leadership and Performance Beyond Expectations. NY: Free Press.

5. Bernardin, H.J. and Russel, J.E.A. (1993). Human Resource Management. Singapore: McGraw Hill, Inc.

6. Greenberg. J. and Baron. R.A. (2003). Behavior in Organizations. New Jersey: Pearson Education, Inc.

7. Hadari, Nawawi. 2005. Metode Penelitian Bidang Sosial. Yogyakarta: Gadjah Mada University Press.

8. Hasibuan, M.S.P. (2001). Organisasi dan Motivasi: Dasar Peningkatan Produktivitas. Jakarta: PT Bumi Aksara.

9. Jung, D.I. and Avolio, B.J. (1999). Effects of Leadership Style and Followers Cultural Orientation on Performance in Group and Individual Task Conditions. Academy of Management Journal. 42, (2), 208-218.

10. Luthans, F. 2006. Perilaku Organisasi, (Alih Bahasa V.A Yuwono, dkk). Edisi Bahasa Indonesia, Yogyakarta: ANDI. 
11. Munawaroh. (2011). Pengaruh gaya kepemimpinan transformasional dan transaksional terhadap kinerja guru di SMP Katolik Wijana Jombang. Malang: Fakultas IImu Adminisitrasi Bisnis Universitas Brawijaya.

12. Rivai, V. and Basri, A.F.M. (2005). Performance Appraisal. Cetakan Pertama, PT. Raja Grafindo Persada, Jakarta.

13. Robbins, S.P. (2007). Perilaku organisasi. Alih Bahasa: Benyamin Molan. Jakarta: Indeks.

14. Sugiyono. (2010). Metode Penelitian Bisnis (Pendekatan Kuantitatif, Kualitatif dan R\&D). Bandung: Alfabeta.

15. Umar, H. (2001). Strategic Management in Action. PT. Gramedia Pustaka Utama. Jakarta.

16. Yukl, G. (2010). Leadership in organizations ( $7^{\text {th }}$ ed.). Upper Saddle River, NJ: Prentice Hall. 